\title{
WASHC5 Gene
}

National Cancer Institute

\section{Source}

National Cancer Institute. WASHC5 Gene. NCI Thesaurus. Code C112062.

This gene is involved in actin polymerization. 